\title{
Politik Pembangunan Organisasi Himpunan Keluarga Besar Mandailing di Sumatera Utara
}

\section{Political Development Organization of Himpunan Keluarga Besar Mandailing in North Sumatra}

\author{
Burhanuddin Siregar*, Heri Kusmanto \& Warjio \\ Program Pasca Sarjana, Magister Ilmu Politik, Fakultas Ilmu Sosial Dan Ilmu Politik, \\ Universitas Sumatera Utara, Indonesia
}

Diterima: 27 Februari 2020; Disetujui: 08 April 2020; Diterbitkan: 01 Juli 2020 \begin{abstract}
Abstrak
Tujuan penelitian ini adalah mengidentifikasi bentuk ekspresi identitas organisasi sosial dalam kebijakan dan agenda politik pembangunan; menganalisis fungsi dan peran HIKMA sebagai aktor politik pembangunan. Penelitian ini menggunakan pendekatan deskriptif kualitatif. Hasil penelitian menunjukkan bahwa kegiatan maupun praktik-praktik pengelolaan dalam lingkungan sosial maupun politik pembangunan organisasi HIKMA yang dilakukan mengandung kausalitas kearifan tradisi budaya dan agama masyarakat Mandailing. Dari nilai-nilai maupun karakter masyarakat Mandailing, ditemukan beberapa prinsip dasar yang meneguhkan praktik kearifan lokal di level komunitas, yaitu nilai kemanfaatan, kekompakan, kekeluargaan kekerabatan warga komunitas juga nilai-nilai kasih sayang dan persatuan yang menjadi bagian budaya luhur Mandailing; serta nilai-nilai keislaman. HIKMA memiliki tali sambungan yang kuat dengan jejak-jejak aktifitas politik pembangunan dengan budaya dan tradisi masyarakat Mandailing masa lampau, yang terekam dalam ekspresi-ekspresi secara simbolik melalui tindakan, bahasa, maupun tradisi dalam kehidupan sehari-hari. HIKMA dan relasinya terhadap politik pembangunan, tidak melibatkan diri dalam politik praktis namun mendorong secara kritis atas perjuangan politik yang bersifat praktis atau berorientasi dan berkolaborasi pada kekuasaan demi membangun daerahnya. Dalam hal ini perjuangan politik yang dilakukan oleh kekuatan-kekuatan politik HIKMA benar-benar mengedepankan kepentingan warga Mandailing khususnya dan masyarakat pada umumnya. Nilai-nilai budaya inilah menjadi semangat dasar dan tujuan perjuangan HIKMA.
\end{abstract}

Kata Kunci: Politik Pembangunan, Identitas Etnis, Organisasi Sosial,

\begin{abstract}
The purpose of this study is to identify forms of expression of social organizational identity in development policy and political agendas; analyze the function and role of HIKMA as a political actor in development. This research use desciptive qualitative approach. The results showed that the activities and management practices in the social and political environment of the HIKMA organization development carried out contained causality of the cultural and religious traditions of the Mandailing people. From the values and character of the Mandailing community, found a number of basic principles that reinforce the practice of local wisdom at the community level, namely the value of expediency, cohesiveness, kinship of community members as well as the values of compassion and unity that are part of Mandailing's noble culture; and Islamic values. HIKMA has a strong connection with the traces of political development activities with the culture and traditions of the Mandailing people of the past, which are recorded in symbolic expressions through actions, languages, and traditions in daily life. HIKMA and its relation to development politics, do not involve themselves in practical politics but encourage critically the political struggles that are practical or oriented and collaborate on power to develop their regions. In this case the political struggle carried out by the political forces of HIKMA really prioritizes the interests of the Mandailing people in particular and society in general. These cultural values are the basic spirit and purpose of the HIKMA struggle.

Keywords: Development Politics, Ethnic Identity, Social Organizations,
\end{abstract}

How to Cite: Siregar, B, Kusmanto, H \& Warjio (2020). Politik Pembangunan Organisasi Himpunan Keluarga Besar Mandailing di Sumatera Utara. PERSPEKTIF, 9 (2): 285-295

*Corresponding author:

E-mail: maulinacutsri@gmail.com

ISSN 2085-0328 (Print)

ISSN 2541-5913 (online) 


\section{PENDAHULUAN}

Penelitian ini mengkaji Politik Pembangunan Organisasi Himpunan Keluarga Besar Mandailing HIKMA di Sumatera Utara. Secara spesifik penelitian ini menjelaskan bagaimana orientasi politik pembangunan organisasi HIKMA dalam mempertahankan dan mengembangkan eksistensinya dalam aktivitas pembangunan di Sumatera Utara.

Sebagai arena dan konteks penelitian yang dibahas terutamanya menyangkut orientasi dan motivasi praktik politik dalam konstelasi pembangunan di Sumatera Utara. Agenda maupun strategi bentuk-bentuk keterlibatan mereka dalam aktivitas politik pembangunan di Sumatera Utara juga menjadi kajian penelitian ini.

Latar belakang penelitian ini diawali bahwa politik pembangunan banyak disebutsebut sebagai sebuah perspektif untuk menganalisis pembangunan dari sudut politik. Keberadaannya diperlukan karena selama ini pembangunan hanya dilihat dari perspektif ekonomi ataupun fisik atau kebendaan saja. Tentu saja, realitas ini menyebabkan analisis terkait politik pembangunan menjadi dangkal dan tidak menjelaskan perspektif politik yang sebenarnya dalam menjelaskan pembangunan.

Sisi keilmuan akademik tentu saja menyebabkan analisis pembangunan dari perspektif politik menjadi "mandeg" tidak berkembang. Yang terjadi dominasi perspektif ekonomi ataupun fisik dalam memahami pembangunan pun tidak terelakkan. Padahal kalau mau jujur, pembangunan merupakan produk politik. Tidak ada pembangunan tanpa ada proses-proses politik. Sebab proses politik inilah yang melahirkan produk politik yaitu pembangunan (Warjio, 2016).

Paparan singkat mengenai konsep politik dan pembangunan tersebut, kita mendapatkan satu gambaran bahwa kedua konsep tersebut memiliki arti dan implementasi tersendiri. Jika kemudian kedua konsep itu digabungkan maka ia akan menjadi konsep yang disebut politik pembangunan. Politik pembangunan sebagai suatu konsep diperlukan untuk menjelaskan bagaimana cara-cara (politik) atau strategi-strategi/aliran tertentu yang digunakan dalam konteks pembangunan mencapai sasarannya.

Cara atau strategi tertentu ini dapat dilakukan oleh negara, institusi/organisasi ataupun partai politik. Oleh yang demikian, sesungguhnya pembangunan pada kebijakannya adalah hasil dari proses politik yang dilakukan oleh pemerintah dengan perangkat-perangkat lain seperti lembaga, partai politik atau bahkan kelompok masyarakat (Warjio, 2013). Dari pengertian seperti ini politik pembangunan merupakan political choice dan di dalamnya terkandung strategi. Political choice terhadap beberapa alternatif, menjangkau mulai dari persoalan asas yaitu epistemologi maupun ontologi (Warjio, 2012).

Menghadirkan pembangunan sebagai produk politik, proses-proses politik menjadi sesuatu yang penting. Di dalamnya "bertarung" berbagai aktor politik dengan berbagai kepentingan mulai dari eksistensi, pembentukan identitas sampai pada pemantapan ideologi. Aktor-aktor politik ini tidak hanya bersifat individu tetapi juga kelompok atau negara. Mereka bisa merefleksikan kepentingan individu tertentu, kepentingan lokal, nasional, bahkan asing.

Provinsi Sumatera Utara dikenal sebagai salah satu provinsi di Indonesia yang tatanan masyarakatnya sangat multicultural karena didiami oleh berbagai kelompok baik suku agama, dan ras. Diantaranya suku Melayu, Mandailing, Simalungun, Karo, Nias, Pakpak dan lain-lain. Sehingga kemajemukan tersebut dipahami sebagai bentuk perbedaan daya adaptasi antar kelompok-kelompok yang berbeda. Akibatnya kompleksitas penduduk yang tinggal di suatu wilayah akan mengakibatkan terjadinya interaksi- interaksi sosial antar individu-individu dengan latar belakang berbeda yang memungkinkan terjadinya perubahan ataupun adanya pergeseran pada identitas etnis itu sendiri.

Situasi sosial segregatif itu menjelaskan kebudayaan masing-masing kelompok etnis ternyata mengalami proses retribalisme. Kebudayaan leluhur dari masing-masing kelompok etnis tidak mengalami pengikisan, melainkan justru menguat kembali. Identitas etnis semakin terpelihara dan loyalitas kepadanya pun semakin dipertinggi oleh warga masing-masing kelompok etnis (Muryanto, 2013).

Kondisi tersebut terefleksi dalam berbagai organisasi baik keagamaan beserta kepemudaannya. Keanggotaan kelompok ini melintasi ikatan-ikatan teritori, namun masih menyiratkan etnisitas. Ada organisasi 
Muhammadiyah yang didominasi warga etnis Minangkabau; Alwashliyah yang didominasi etnis Mandailing dan Melayu; Huria Kristen Batak Protestan; Gereja Batak Karo Protestan; Gereja Kristen Protestan Simalungun; Gereja Kristen Protestan Angkola; Gereja Methodist Indonesia (Cina); dan seterusnya (Muryanto, 2013)

Berdasarkan kondisi di atas menjadikan alasan yang menarik untuk meneliti organisasi HIKMA ini lebih jauh. Alasannya, pertama keberadaan Organisasi HIKMA sebagai arena dan konteks penelitian yang akan dibahas memiliki dasar yang kuat dengan estimasi massa yang banyak dan kesolidan yang mumpuni. Di antara asosiasi-asosiasi dan organisasi suku yang ada di Sumatera Utara, HIKMA (Himpunan Keluarga Besar Mandailing) ini dapat dikatakan sebagai asosiasi yang termasuk survive di Sumatera Utara.

Kedua, HIKMA juga salah satu organisasi berbasis terlama (32 tahun) yang ada di Sumatera Utara sejak dibentuk pada 4 Mei 1986 oleh tokoh seperti Alm. H Yusuf Effendi Nasution (ketua umum), Marwan Fauzi Lubis, H. Samuel Lubis, Mansaraja Lelo Lubis, Drs.Asnan Daud Dalimunte, dan Lukman Lubis. Kini memiliki pengurus di 17 tingkat II (Kab/Kota), 141 Kecamatan (tingkat III) dan 500 Komisaris (Kelurahan/Desa) ditambah lagi dengan organisasi-organisasi binaan HIKMA.

Ketiga, HIKMA terbentuk bukanlah semata-mata ditujukan untuk mempertahankan survival ekonomi anggota saja, tetapi juga untuk mempertahankan dan memperkuat diri sebagai kelompok dalam menghadapai tantangan dan perubahan dari luar. Tidak dapat dipungkiri lagi bahwa juga banyak yang terjun ke dalam politik praktis dengan memanfaatkan kesolidan sebagai anggota HIKMA.

\section{METODE PENELITIAN}

Penelitian ini menggunakan pendekatan metode kualitatif deskriptif. Secara teoritis penelitian kualitatif adalah suatu pendekatan penelitian yang memberikan penekanan pada data yang dihasilkan berupa data deskriptif, yakni kata-kata tertulis ataupun lisan dari objek atau orang yang diamati (Moleong, 2012).
Penelitian ini menggunakan pendekatan analisis kualitatif dan strategi studi kasus adalah cara yang cocok dalam mendeskripsikan penelitian ini. Dimana dalam penelitian ini hanya hendak memahami serta melakukan interpretasi terhadap interaksi sosial diantara para aktor dalam sebuah konteks sosial, temporal, dan historis tertentu. Dengan kata lain, secara metode, penelitian ini sedikit atau bahkan tidak mengedepankan metode statistik dan matematik, tetapi memanfaatkan analisis verbal dan kualitatif.

Pendekatan ini menekankan sifat realita yang terbangun secara sosial, hubungan erat antara peneliti dengan subjek yang diteliti, dan tekanan situasi yang membentuk penyelidikan. Selain itu dalam penelitian ini mementingkan sifat penyelidikan yang sarat-nilai. Mencari jawaban atas pertanyaan-pertanyaan yang menyoroti cara munculnya pengalaman sosial sekaligus perolehan maknanya (Denzin,2009). Sehingga pada konteks tersebut, penelitian ini sangat cocok dengan menggunakan pendekatan penelitian kualitatif.

Strategy riset yang dipakai adalah dengan menggunakan metode studi kasus. Dijelaskan oleh Yin (2008) bahwa metode studi kasus merupakan suatu inkuiri empiris yang menyelidiki fenomena di dalam konteks kehidupan nyata, bilamana batas-batas antara fenomena dan konteks tak tampak dengan tegas, dan dimana multisumber dimanfaatkan.

Data diperoleh langsung dari orang yang menjadi sumber data. Untuk penelitian ini yang menjadi sumber data adalah pengurus organisasi HIKMA baik ketua, sekretaris, pengurus daerah. Selain itu juga para sesepuh dan tokoh adat Mandailing yang pernah tergabung dalam organisasi HIKMA, Ketua Umum HIKMA Sumut: Aswin Parinduri, Sekretaris Umum HIKMA Sumut: Parlindungan Batu Bara, Ketua Bidang Kesenian dan Budaya HIKMA Sumut: Bahsan Parinduri, Tokoh Mandailing dan HIKMA: Pandapotan Nasution, Ketua PD Hikma Kota Medan: Paruhum Alam Sah Lubis

Teknik pengumpulan data yang relevan untuk digunakan dalam penelitian ini meliputi: Wawancara dilakukan terhadap responden dengan menggunakan pertanyaan-pertanyaan terstruktur yang memuat pokok-pokok permasalahan yang berhubungan dengan 
tujuan penelitian. Adapun responden tersebut diantaranya orang-orang yang telah disebutkan dalam sumber data penelitian. Teknik ini dilakukan dengan cara meneliti dokumen-dokumen berupa arsip yang ada pada kantor HIKMA maupun data perpustakaan, bahkan ejurnal dan literatureliteratur dan laporan termasuk laporan media cetak yang berkaitan dengan tema penelitian

Teknik analisis dan penafsiran data dalam penelitian ini mengikuti langkahlangkah yang direkomendasikan oleh Yin (2006:133), yang menyatakan bahwa analisis data dilakukan dengan penelaahan, kategorisasi, melakukan tabulasi data dan atau mengkombinasikan bukti untuk menjawab pertanyaan penelitian. Prosedur ini senada dengan prosedur yang direkomendasikan oleh Moleong (2001:190), bahwa proses analisis data dimulai dengan: menelaah seluruh data yang tersedia dari berbagai sumber, dalam hal ini adalah dari hasil wawancara, kuesioner, maupun analisis dokumen; mengadakan apa yang dinamakan reduksi data yang dilakukan dengan jalan membuat rangkuman yang inti, proses dan pernyataan-pernyataan kunci yang perlu dijaga agar tetap berada didalamnya; menyusunnya kedalam satuan-satuan untuk kemudian dikategorisasikan; melakukan pemeriksaan keabsahan data dengan teknik tertentu; penafsiran data dan kesimpulan dari sebuah verifikasi data.

Dalam pengolahan data, data yang telah dikumpulkan dideskripsikan sesuai dengan data dan selanjutnya dilakukan tahapan klasifikasi data. Tahap ini merupakan tahapan yang sangat penting karena semua data yang telah diklasifikasikan tersebut kemudian dianalisis berdasarkan pemahaman pada landasan teori. Selanjutnya dianalisis menggunakan metode kualitatif dari perspektif deskriptif. Melalui pendekatan teori yang telah disebutkan sebelumnya, fenomenafenomena dan fakta yang ditemukan pada saat observasi dihubungkan dan didialogkan satu persatu. Dengan menghubungkan antar fenomena dengan teori yang ada akan ditemukan hubungan sebab-akibat. Pada akhirnya akan didapatkan temuan fenomenafenomena di lapangan yang dapat digolongkan sebagai jawaban Masalah Politik Pembangunan Organisasi HIKMA di Sumatera Utara.
Tahap ini merupakan tahapan akhir dari proses analisis data, pada proses ini dilakukan penilaian/evaluasi keseluruhan terhadap semua proses yang telah dilaksanakan. Tahapan ini akan menyajikan deskripsi dan analisis data yang telah dilakukan serta dibuatkan kesimpulan seluruh hasil analisa.

\section{HASIL DAN PEMBAHASAN \\ Motif Politik Pembangunan HIKMA}

Keanekaragamanman suku, etnis dan budaya di kota Medan membawa suatu pandangan bahwa tatanan masyarakat kota ini sangat multikultur ataupun heterogen. Artinya begitu banyak identitas yang berbeda satu sama lain yang hidup dalam bermasyarakat. Interaksi tersebut lambat laun bisa mengalami pergeseran ataupun menyebabkan memudarnya budaya masing-masing. Jadi setiap kelompok etnis membutuhkan usaha untuk mempertahankan identitas etnisnya baik dalam berpolitik, sosial masyarakat bahkan ekonomi.

Usaha tersebut lewat berbagai media dan simbol-simbol budaya. Simbol-simbol tersebut akan menggambarkan bahwa dia berasal dari etnis tertentu. Pengungkapan identitas ini sering dilakukan secara aktif dan sadar, seperti memakai pakaian adat, perhiasan, dan bahasa daerah agar orang dari kelompok lainnya mengetahui identitas dan batas-batas antara mereka dengan orang lain. Ekspresi ini dibutuhkan untuk mengukuhkan kesetiaan anggota kelompok etnis tersebut.

Strategi sosial budaya etnis Mandailing dalam mempertahankan identitas etnis diperantauan lainnya dapat dilihat dari aktifitas maupun nilai-nilai sosial budaya seperti poda na lima Mandailing atau lima adab masyarakat Mandailing yang masih tertanam dalam diri masyarakat Mandailing. Adapun isi poda na lima tersebut adalah sebagai berikut:

1. Paias Rohamu yang berarti bersihkan hatimu/ jiwa kita

2. Paias Pamatangmu yang berarti raga kita/ harus sehat dan mempunyai fisik yang kuat, ibarat pemimpin jangan ada yang cacat. Jika dirimu kuat tentu kamu akan cerdas, tentu kamu akan pintar

3. Paias Pakaianmu yang berarti tiangkatkan ekonomimu/ perbaiki hidupmu

4. Paias Bagasmu yang berarti ketika ekonomi kita bagus, tentu tempat tinggal 
kita bagus, keluarga kita berkecukupan artinya tidak hina

5. Paias Pakaranganmu yang berarti bersihkanlah semua sekitar rumahmu artinya memperbaiki saudaramu, tetanggamu dan masyarakatmu.

Pada konteks ini, sebagai upaya melestarikan nilai-nilai tersebut, anggota maupun pengurus organisasi HIKMA setiap pelantikan nilai-nilai poda na lima wajib diikrarkan. HIKMA bagi masyarakat Mandailing perantau merupakan wadah maupun gambaran mengenai tradisi masyarakat Mandailing yang berdomisili di kota Medan.

Orientasi berdirinya organisasi HIKMA diawal pembentukannya juga memang untuk mempertahankan ataupun melestarikan kebudayaan adat istiadat suku Mandailing. Sehingga HIKMA mempunyai dampak yang sangat besar karena dapat menghimpun kembali orang-orang Mandailing, dampaknya tersebut bukan hanya bagi masyarakat Mandailing tapi juga diluar masyarakat Mandailing.

Keluarga besar HIKMA bukan saja masyarakat yang bersuku Mandailing saja, tetapi juga bisa juga orang yang bersuku lain. HIKMA beranggapan bahwa orang lain tersebut pasti ada memiliki hubungan keluarga dengan keturunan suku Mandailing. Kalaupun tidak saudaranya pasti ada memiliki hubungan dengan keluarga Mandailing. Hal ini tergambarkan dalam nilai-nilai identitas HIKMA yaitu Markoum (bersaudara), bahwa semua orang Mandailing adalah saudara ataupun yang memiliki hubungan dengan keluarga Mandailing juga bersaudara.

Jadi setiap yang bersentuhan dengan orang Mandailing adalah bersaudara. Apalagi yang tinggal di perantauan. Hubungan kekerabatan selalu dikedepankan dan dijaga dengan baik. Bagi masyarakat Mandailing perantau mendahulukan kekerabatan atau saudara merupakan nilai yang utama.

Banyak warga Mandailing perantau di kota Medan yang telah berhasil, memiliki usaha menengah keatas, tidak terkecuali yang pernah dan sedang menjabat di lembaga pendidikan maupun pemerintahan di kota Medan. Masih memegang prinsip kekerabatan ini dan masih dibudayakan dalam kehidupan sosial masyarakat. Dalam memperteguh sistem kekerabatan ini umum bisa terdapat diantara orang-orang yang berhubungan kekerabatan dekat, saling memberi hadiah apabila ada aktivitas budaya, perkawinan, sebagian maupun kerabat menghadapi musibah, kesulitan. Saling memberi hadiah, ikut melibatkan diri pada setiap acara penting adalah sebuah aktifitas untuk memelihara kedekatan sesama suku Mandailing perantau.

Bagi HIKMA sendiri prinsip dan perilaku kekerabatan itu adalah sebuah penilaian untuk memperkuat adaptasi. Setelah mereka perantau bermukim di kota Medan, mereka menemukan organisasi kekerabatan seperti perkumpulan asal desa mereka (istilah di kampung satu luhat) dan perkumpulan marga dengan boru yang kegiatannya silaturahmi dan pengajian. Serta ada lagi perkumpulan pelajar dan mahasiswa asal Tapanuli Selatan yang anggotanya berasal dari beberapa perguruan tinggi negeri dan perguruan tinggi swasta.

Semua aktifitas organisasi dapat mereka gunakan sebagai tempat adaptasi, untuk mendapatkan informasi di kota Medan. Seperti melakukan pertemuan bulanan, yang diisi dengan pengajian agama dan membicarakan adat budaya, kekerabatan mereka yang berasal dari suku Mandailing. Kegiatan ini adalah sebuah upaya silaturahmi dan menjalin persatuan sesama warga Mandailing. Bagi masyarakat Mandailing perantau, yang telah migrasi duluan ke Medan, dengan pendatang (perantau) yang baru datang ke kota Medan, terdapat interaksi, integrasi, adaptasi bersama bagi kehidupan orang yang merantau ke kota Medan.

Pengenalan antara pendatang baru (perantau) sangat intensif, tentang informasi, asal desa, asal marga, asal pendidikan, tempat tinggal, untuk kepentingan integrasi sosial mereka. Keadaan yang terbuka tentang adaptasi, mencari usaha untuk kepentingan ekonomi, tentunya yang sesuai dengan kemampuan yang mereka miliki, menuju kesempatan mendapat kehidupan baru di kota Medan.

Tidak heran bagi perantau, biasanya mengikuti dan masuk dalam kegiatan perkumpulan, baik semarga atau parsadaan maupun persatuan atas pertalian satu daerah asal atau kampung. Parsadaan merupakan fenomena yang terjadi di daerah perantauan. Tujuan berkumpulnya mereka dalam perkumpulan marga di kota pada mulanya untuk saling membantu diantara sesama 
mereka, meneguhkan kebersamaan dalam persoalan tantangan hidup terutama dalam kesulitan ekonomi.

Keberadaan perkumpulan marga biasanya dibentuk untuk memberikan arahan tentang marga atau silsilah/ tarombo. Sehingga perkumpulan marga bisa memelihara identitas dan akar budaya. Dengan begitu, para perantau setiap marga bisa mengatasi persoalan dan kekurangan yang terjadi dan dapat diselesaikan dengan kebersamaan.

Dalam pandangan suku Mandailing, tarombo marga dapat mengurutkan silsilah, yaitu menentukan diurutan generasi keberapa seseorang berada, untuk dapat saling bertegur atau memanggil. Juga untuk menentukan siapa-siapa saja yang hubungannya paling dekat kepada seseorang yang memerlukan bantuan.

Setiap generasi dapat memahami terhadap adat budayanya dan agama. Tujuannya untuk mengetahui asal usul atau menjaga marganya agar tidak hilang. Proses melestarikan marga dapat dilihat dari upacaraupacara adat dan keagamaan yang berkaitan dengan kelahiran, perkawinan, dan kematian seseorang juga diselenggarakan dengan melibatkan orang-orang dalam lingkungan perkumpulan marga. Selebihnya perkumpulan marga juga berfungsi sebagai institusi penyelesaian sengketa yang berkaitan dengan masalah-masalah keluarga dan adat (Panjaitan dalam Irianto, 2005)

Bagi masyarakat Mandailing perantau di kota, perkumpulan marga ini sangat dibutuhkan. Sebab betapapun seseorang mengidentikkan dirinya sebagai orang modern di kota besar, namun ketika berhadapan dengan masalah keluarga, maka ia akan kembali kepada nilai-nilai tradisional lama, sehingga ia memiliki dua ciri sekaligus yaitu superculture dan biculturalism (Geertz dalam Irianto, 2005). Bagaimanapun juga aktivitas dalam perkumpulan marga, yang diintensifkan melalui berbagai pertemuan dan pesta adat, sangat memperkuat dan mempertebal rasa solidaritas kelompok yang bersangkutan

Bagi masyarakat Mandailing perantau lebih dulu dan telah berhasil di kota Medan, ada sebuah beban moral budaya. Sehingga keterlibatan ikut menolong kerabatnya yang datang ke kota Medan adalah sebuah keniscayaan. Hal itu merupakan penghargaan pada dirinya bahkan masyarakat Mandailing yang ada dikampung. Tidak sedikit warga perantau yang berhasil dan membantu kerabatnya mendapatkan prestise yang baik bila ia mudik (saat lebaran) ke kampung halamannya.

Kedatangannya ke kampung halaman disambut dengan baik dan gembira oleh masyarakat desanya. Upacara upah-upah dilakukan sebagai bentuk penghormatan dalam penyambutan keluarganya, dengan doa agar sehat dan panjang umurnya, kuasa keselamatan, kesentosaan, kebahagiaan dan berbagai macam kebaikan lainnya. Hal ini sebagai perlambang penghargaan dan ucapan terima kasih (Pengaduan Lubis dan B. Lubis 1998)

Melalui HIKMA masyarakat Mandailing perantau bisa mengekpresikan identitas etnis mereka. Organisasi ini telah menjadi mekanisme adaptasi untuk kehidupan di kota Medan juga untuk mendukung kepentingankepentingan tradisi dan budaya Mandailing. HIKMA dijadikan wadah bagi mereka untuk memperbaiki keadaan-keadaan di kampung mereka atau bertindak sebagai "penyangga" bagi para perantau baru yang masih kebingungan dengan lingkungan di kota. Sehingga HIKMA dapat dimanipulasi untuk mengekspresikan kepentingan-kepentingan masyarakat Mandailing perantau maupun yang sudah lama menetap di kota Medan.

\section{Fungsi dan Peran HIKMA sebagai Aktor Politik Pembangunan}

Memahami fungsi dan peran HIKMA dalam konteks pembangunan memiliki kedudukan penting. Peran tersebut akan memberikan gambaran HIKMA sebagai aktor politik pembangunan berdasarkan prosesproses politik yang dilakukan. HIKMA sebagai aktor bukanlah hanya sebagai organisasi, namun HIKMA hidup dalam ruang satu sistem politik yang didalamnya terdapat nilai, ide, pengaruh, jejaring yang dimiliki.

HIKMA memiliki ciri khas dan pendekatan didalam mengimplementasikan praktik-praktik politiknya. Mereka mengadakan intensitas komunikasi sebagai mitra pemerintah dalam konteks pembangunan. Banyak program, fungsi dan peran yang telah dilakukan HIKMA melalui pemberdayaan terhadap masyarakat khususnya warga Mandailing perantauan, membangun jejaring dan pemberdayaan 
ekonomi. Memberikan dan membuka jalan untuk lapangan pekerjaan. Tujuanya membantu mereka untuk meningkatkan kualitas hidup. Dengan cara ini, HIKMA berkontribusi terhadap pembangunan masyarakat yang berkelanjutan. HIKMA memobilisasi masyarakatnya menemukan potensinya agar mandiri.

\section{Politik Akomodatif HIKMA dan Relasinya terhadap Pembangunan}

HIKMA diukur dengan kriteria apapun, adalah organisasi besar juga merupakan organisasi yang tua bagi warga Mandailing perantau maupun yang bukan. Organisasi yang besar dan tua ini telah menjejakkan langkah dalam eksistensinya. Setiap anggota kader HIKMA selalu ditekankan untuk menyadari bahwa dirinya adalah keturunan suku Mandailing dan harus membesarkan sesamanya. Agama dan adat istiadat harus menjiwai setiap langkah seluruh anggota maupun masyarakat Mandailing umumnya. Dijalankan secara simultan dan serempak dalam satu tindakan.

Nama besar dan tua tersebut karena selama ini HIKMA dibesarkan atas kesadaran dan kecintaan warga suku Mandailing itu sendiri untuk melestarikan dan memajukan identitasnya di dalam masyarakat. Mereka (anggota atau warga Mandailing khususnya) banyak yang berhasil hasil pengkaderan atau karena nama besar HIKMA. Mereka sering menggunakan relasi atau jaringan identitas dalam mendapatkan posisi pekerjaan. Tidak segan bahkan terkadang lebih mengutamakan pada pendekatan kekerabatan, kemargaan dan sejarah keluarga terlebih dahulu. Mereka mendapatkan keuntungan dari kondisi itu. Atas dasar itulah salah satu alasan mereka berhimpun. Memajukan diri, saudaranya sendiri dan kampungnya. Sangat eksklusif memang.

Walaupun ini adalah perkumpulan suku Mandailing namun tidak menutup kemungkinan bagi etnis lain untuk ikut bergabung dengan HIKMA. Sehingga semua anggota HIKMA bukanlah berasal dari suku Mandailing saja tetapi ada juga etnis yang lain bergabung dengan perkumpulan ini, namun jumlahnya sangat sedikit.

Tidak seperti organisasi keagamaan Muhammadiyah atau NU yang lebih modern dan plural. Banyak orang-orang besar yang merupakan hasil pengkaderan dari organisasi tersebut. HIKMA sedikit berbeda, eksistensinya lebih menekankan atas dasar satu identitas marga, satu daerah "kampung" dan agama.

Banyak anggota maupun keluarga besar Mandailing yang tergabung dalam HIKMA di kota Medan umumnya mendominasi instansiinstansi pemerintahan maupun bidang pendidikan. Dengan adanya dominasi ini menyebabkan adanya pengakuan masyarakat diluar keturunan Mandailing terhadap eksistensinya itu. Indikasinya mereka senantiasa mendahulukan kelompok kekerabatan mereka.

Inilah salah satu alasan penting mengapa mereka (para perantau) selalu berjuang untuk menduduki posisi strategis di pemerintahan, maupun perusahaan swasta. Karena dengan upaya-upaya itu mereka yang telah menetap (migran permanent) dapat membantu dengan memberikan kesempatan bagi kerabat mereka yang masih menganggur untuk mendapatkan pekerjaan. Sehingga walaupun status mereka hanya pendatang tapi mereka bisa menonjol di instansi-instansi pemerintahan Kota Medan. Strategi ini menjadikan salah satu kunci bagi HIKMA untuk dapat mempertahankan identitasnya.

Pedoman ataupun nilai-nilai hidup masyarakat Mandailing tersebut tercermin dalam setiap aktifitas yang disebut dalam sembilan nilai utama seperti Kekerabatan, Religi (Islam), Hagabeon, Hamajuon, Hasangapon, Hamaraon, Uhum, Pengayoman dan kelola konflik. Dengan adanya konsep tersebut dijadikan sebagai pedoman yang memberi arah dan orientasi pada kehidupan masyarakat Mandailing. Konsep ini selanjutnya selalu digunakan sebagai inspirasi pegangan hidup untuk keberhasilan masingmasing masyarakatnya.

Konteks inilah yang bisa menjelaskan bahwa identitas etnis bisa memainkan peranan penting dalam perpolitikan. Tidak hanya institusi, aktor dan budaya lokal juga dapat memainkan peran didalam politik (Klinken, 2007, Warjio, 2016).

Namun, eksklusifitas tersebut menjadikan ruang gerak yang sempit. Tradisi politik warga Mandailing baik anggota maupun keluarga besar yang tergabung di dalam HIKMA dari generasi ke generasi cenderung legalistik dan formalistik dalam merumuskan 
gerakan politiknya, sangat monoton dan terlalu berlebihan dalam mengutamakan simbol-simbol budaya dan keIslamanya. Dinamika gerakan HIKMA sangat kondisional hingga mengalami stagnasi karena terjadinya penumpulan kreativitas. Lebih daripada itu, HIKMA cenderung monolitik, homogen, dan serbaseragam baik dalam format gerakan politik, sosial maupun corak pemikiran keagamaanya.

Nama besar HIKMA seiring dengan jumlah masyarakat Mandailing yang ada di kota Medan. Jumlah anggota tanpa kartu, simpatisan atau anggota yang termasuk dalam kategori kehormatan memang cukup banyak. Kebanyakan orang menganggap ketika dia bersuku Mandailing sudah pasti keluarga HIKMA. Tetapi jumlah yang banyak tersebut tidak didukung oleh data tertulis, semuanya menjadi sebatas klaim. Dan, yang namanya klaim tentunya bisa benar dan bisa pula salah. Alhasil hanya sebatas euforia jumlah yang banyak itu.

Sejak awal, dinamika yang sering timbul kepermukaan bahwa HIKMA mengalami kemandekan dalam bidang pembaharuan, mengalami keterjebakan dalam rutinisme dibidang budaya, sosial, dan agama. Namun mengalami pemiskinan dalam bidang ekonomi dan politik. Bisa dikatakan bahwa inti persoalan paling fundamental yang dihadapi HIKMA adalah persoalan manajemen dan kepemimpinan. Persoalan ini kalau bukan hanya menjadi masalah, malah dilematis yang cukup serius. Sehingga bagi anggota maupun keluarga besar HIKMA membutuhkan figur pemimpin yang berkualitas dalam meneruskan keberadaan HIKMA.

Dinamika yang berkembang telah menjadikan pelajaran yang baik bagi HIKMA. Di usia yang sudah 32 tahun. Dalam perjalanannya mengalami kondisi naik dan turun, bahkan pernah vakum. Pada tahun 2013, HIKMA kembali bangkit dengan masa bakti hingga Juni 2018. Antusias untuk berubah dan keinginan untuk maju oleh anggota maupun keluarga besar HIKMA terlihat jelas dalam Konfrensi Daerah (Konferda) VI HIKMA Sumut yang berlangsung 23-25 April 2018 di Asrama Haji Medan.

Ketua Umum PD HIKMA Sumut H Aswin Parinduri SH yang terpilih secara aklamasi berharap HIKMA mampu mempersatukan masyarakat Mandailing di Sumut, sehingga kedepannya warga Mandailing jadi barometer keberagaman di Sumatera Utara (https://www.mandailingonline.com). Selain itu, Konferda HIKMA Sumut juga merekomendasikan pembentukan Pengurus Pimpinan Pusat HIKMA. Sekitar 21 Pengurus Pimpinan Daerah Hikma se-Sumatera Utara dengan jumlah peserta sekitar 400 orang hadir mensukseskan Konferda.

Tidak hanya bersinergi dengan pemerintah, dalam menjaga identitas tradisi dan budaya Mandailing oleh HIKMA di kota Medan melakukan upaya penyelesaian pembangunan Sopo Godang Mandailing kini menjadi pekerjaan rumah bagi kepengurusan HIKMA Sumatera Utara periode 2018-2023 dibawah kepemimpinan H Aswin Parinduri SH. Kini. Banyak kalangan dari masyarakat Mandailing, sangat berharap Sopo Godang Mandaling (rumah besar) ini segera terwujud. Membangun Sopo Godang di Medan merupakan cita-cita pendiri HIKMA sebagai upaya menjaga nilai-nilai luhur dan tradisi masyarakat Mandailing di tanah perantauan.

Untuk HIKMA daerah kota Medan sendiri juga memiliki peran yang cukup signifikan bagi proses pembangunan. HIKMA mampu menjadi mitra pembangunan daerah. Pandangan ini sejalan dengan apa yang disampaikan oleh wakil walikota Medan Ir. Ahkyar Nasution dalam sambutannya saat menghadiri acara HUT HIKMA ke-30 yang dirangkai dengan pelantikan Pengurus HIKMA Kota Medan serta pengurus Kecamatan se-Kota Medan priode 2016-2019.

Bagi pemerintah kota Medan, HIKMA merupakan salah satu perkumpulan yang turut memberikan sumbangsih terhadap program pembangunan di Sumaatera Utara pada umumnya dan Kota Medan khususnya. Peranan HIKMA di Kota Medan tidak terlepas dari tujuan untuk menghidupkan fungsi-fungsi yang ada dalam suatu organisasi, seperti fungsi agama, budaya, kepemudaan, pendidikan, pelatihan dan sumber daya manusia serta lainnya (https://pemkomedan.go.id/).

Pelantikan pengurus HIKMA kota Medan menjadikan momentum bagi anggota maupun seluruh masyarakat Mandailing. Orientasinya jelas agar HIKMA dapat menguatkan silaturahmi serta bahu membahu memberikan peranan nyata. Tidak saja membantu masyarakat Mandailing tetapi masyarakat lainnya di Kota Medan, dan menjaga persatuan 
dan kesatuan sesama masyarakat Mandailing maupun masyarakat luas.

Sehingga dalam konteks dan perspektif ini, HIKMA kini tidak hanya melakukan langkah genial di tengah-tengah stagnasi strategi politik sejak dulu hanya "begitu-begitu saja", tetapi juga merintis tradisi politik yang sama sekali baru, berani dan berisiko. Dan sebagai terobosan genial yang inkonvensional, langkah ini dapat disebut sebagai suatu fase dalam dinamika pembaharuan pemikiran dan aktivisme politik praktis HIKMA yang selangkah lebih berani dari generasi sebelumnya.

Kecenderungan platform politik maupun aktivitas politik generasi sebelum-sebelumnya sangat doktriner legalistik dan formalistik dalam merumuskan cita-cita politiknya, sangat monoton dalam strategi dan terlalu berlebihan dalam mengutamakan simbol-simbol tradisi budaya dan keislaman.

HIKMA kini lebih egaliter, adaptif dan akomodatif kepada partai politik (golongan) politik yang sedang berkuasa. Sikap ini dimanifestasikan dan diimplementasikan dalam sikap politik yang berkembang saat ini. HIKMA dan pemerintah daerah selalu bersinergi dalam pembangunan. HIKMA selalu bersikap terbuka untuk kemajuan dan selama tidak berseberangan dengan nilai-nilai budaya dan agama.

\section{SIMPULAN}

Ekspresi Identitas Budaya dan Keislaman Sebagai Motif Politik Pembangunan HIKMA. Kegiatan maupun praktik-praktik pengelolaan dalam lingkungan sosial maupun politik pembangunan organisasi HIKMA yang dilakukan merupakan bentuk-bentuk pengelolaan yang mengandung kualitas kearifan tradisi budaya dan agama masyarakat Mandailing, karena mampu bertahan hingga kini dan dan masih fungsional untuk memenuhi kebutuhan dan mengatasi problema yang dihadapi oleh anggota maupun keluarga besar HIKMA. Proses maupun dinamika politik pembangunan HIKMA yang mereka lakukan berdimensi pada pendekatan kearifan budaya karena disana sudah merangkum adanya akumulasi pengalaman, pengetahuan, praktik, keyakinan dan nilai-nilai luhur yang mendasari bertahannya eksistensi organisasi HIKMA. Dari nilai-nilai maupun karakter masyarakat Mandailing khususnya
HIKMA yang diteliti ditemukan beberapa prinsip dasar yang meneguhkan praktik kearifan budaya di level komunitas, yaitu nilai kemanfaatan, kekompakan, kekeluargaan kekerabatan warga komunitas juga nilai-nilai kasih sayang dan persatuan yang menjadi bagian budaya luhur Mandailing; serta nilainilai keislaman. Jika diteliti lebih jauh kaitannya dengan kebudayaan tradisional Mandailing masa lampau, terlihat bahwa prinsip-prinsip dasar yang menjadi peneguh nilai maupun prinsip dasar HIKMA berikut atribut-atribut penting yang melekat pada HIKMA memiliki tali sambungan yang kuat dengan jejak-jejak aktifitas politik pembangunan yang dimiliki oleh HIKMA dengan budaya dan tradisi masyarakat Mandailing masa lampau, yang terekam dalam ekspresi-ekspresi secara simbolik melalui tindakan, bahasa, maupun tradisi dalam kehidupan sehari-hari.

HIKMA Sebagai Politik Akomodatif dan Gerakan Politik Identitas. Adanya kaitan atau relasi antara prinsip-prinsip yang mendasari persistensi HIKMA terhadap praktik kearifan budaya di masa kini dengan khasanah nilai budaya Mandailing. Dengan mengelaborasi lebih jauh nilai-nilai tersebut dalam relasinya terhadap politik pembangunan, HIKMA dalam perkembangannya dengan potensi kekuatan anggota yang terlibat di pemerintahan daerah, HIKMA kini juga mendorong secara kritis atas perjuangan politik yang bersifat praktis atau berorientasi pada kekuasaan untuk dijalankan dengan sebaik-baiknya bahkan dapat berkolaborasi dengan baik demi membangun daerahnya. Perjuangan politik yang dilakukan oleh kekuatan-kekuatan politik HIKMA benarbenar mengedepankan kepentingan warga Mandailing khususnya dan masyarakat pada umumnya. Nilai-nilai budaya inilah menjadi semangat dasar dan tujuan perjuangan HIKMA. Namun, bentuk gerakan politik identitas HIKMA tersebut membentuk sebuah dilematis politik yang ambigu. Sebab HIKMA bukanlah sebuah organisasi yang mengandung politik, namun tidak apolitis. Organisasi ini adalah sebuah sarana paradaton yaitu sebagai pusat adat yang tetap melestarikan adat istiadat serta budaya suku Mandailing. Prinsipnya HIKMA lebih mengutamakan kepentingan dan eksistensi Mandailing, tidak berpolitik namun tidak apolitis. HIKMA sebagai mitra pemerintah, tetap memainkan peran 
politiknya sebagai wujud nilai tradisi budaya Mandailing agar dapat mempengaruhi proses dan kebijakan pemerintah. Tindakannya tetap harus memegang teguh cita-cita luhur tradisi masyarakat Mandailing. HIKMA dijadikan perekat kekuatan warga Mandailing dan berfungsi sebagai wahana pendidikan politik untuk mempertahankan kepentingannya.

\section{DAFTAR PUSTAKA}

Acemoglu, D and Robinson, A.t.th. (2012). The Origin of Power, Prosperity and Poverty. New York: Crown Bussines.

Arikunto, S. (2002). Prosedur Penelitian (Suatu Pendekatan Praktek). Jakarta: Penerbit Rineka Cipta.

Lubis, A.R. (2004). The Politics of Identity Construction: The Case of the Mandailing People. The Asian Face of Globalisation: Reconstructing Identities, Institutions and Resources. The Papers of the 2001 API Fellows Edited by Ricardo G. Abad. The Nippon Foundation, Tokyo

Aristotle, (1959). Politics, terjemahan. H. Rackham. Cambridge: Harvard University Press.

Azra, A, (2007). Identitas dan Krisis Budaya, Membangun

MultikulturalismIndonesia.http://www.kon gresbud.budpar.go.id/58\%20ayyumardi $\% 20$ azra.htm

Barth, F. (1988). Kelompok Etnik dan Batasannya Tatatan Sosial dari Perbedaan Kebudayaan. Jakarta : Universitas Indonesia - UI press

Calvert, P, \& Susan, C. (2001). Politics And Society In The Third World. England: Longman Education

Death, C. (2010). Governing Sustainable Development: Parthnership, Protest and Power. Oxford: Routledge.

Denzin, N.K. and Lincoln, Y.S. (2009). Handbook of Qualitative Research, Yogyakarta: Pustaka Pelajar.

Durado, N.C. Peran Organisasi Masyarakat Dalam Mengontrol Kebijakan (dalam httpsejournal.unsrat.ac.idindex).

Feillard, A. (1995). $N U$ vis a vis Negara Pencarian Isi, Bentuk dan Makna (terjemahan dari Islam et Armee Dans L'Indonesie Contemporaine Les Pionniers de la Tradition). Yogyakarta: LkiS

Gasper, D. (2004). the of Development: from economic to human Development. Edinburg: Edinburg University Press

Goodin, R.E. \& Klingeman, H.D, (1996). A New Handbook of Political Science, New York: Oxford University Press.

Haboddin, H. (2007). Menguatnya Politik Identitas di Ranah Lokal. Malang: Jurnal Studi Pemerintahan Universitas Barawijaya
Heywood, A. (2004). Politics Theory (edisi ketiga). New York: Palgrave Macmillan.

Mauliyawati, I. Sundarso, K. (2004). Studi Evaluasi Kinerja "Dialogue" JIAKP, Vol.1, No.1, Januari.

Irianto, S. (2005). Perempuan di Antara Berbagai Pilihan Hukum. Jakarta: Yayasan Obor Indonesia

McAuley, J.W. (2003). An Introduction to Politics, State and Society. London: SAGE Publication.

Hilda, L, (2016). Revitalisasi Kearifan Lokal Dalihan $\mathrm{Na}$ Tolu Masyarakat Muslim Mandailing Dalam Menjaga Harmonisasi Lingkungan Hidup. Jurnal MIQOT Vol. Xl No. 1 JanuariJuni.

May. L. \& Chobanian, S.C.. Etika Terapan : Sebuah Pendekatan Multikultural. Terjemahan: Sinta Carolina dan Dadang Rusbiantoro, Yogyakarta : Tiara Wacana

Lubis, P.Z, \& Lubis, B,Z (1998), Sipirok Na Soli, Bianglala Kebudayaan Masyarakat Sipirok. Universitas Sumatera Utara: USU Press

Lubis, Z. Dkk. (2012). Kearifan Lokal Masyarakat Mandailing Dalam Tata Kelola Sumberdaya Alam Dan Lingkungan Sosial. Balai Pelestarian Nilai Budaya Banda Aceh Direktorat Jenderal Kebudayaan Kementerian Pendidikan dan Kebudayaan RI

Matondang, A. (2010). Tek Tek Mula Ni Gondang Somba Mula Ni Tortor Visual etnografi Musikal Batak-Mandailing http://www.academia.edu/

Amin, M. (2013). Politik Layar Terkembang (Lintasan Sejarah Pemuda Pancasila Sumatera Utara Dalam Kekuasaan). Medan: Vote Institute.

Moleong, L.J. (2012). Metodologi Penelitian Kualitatif. Bandung: PT. Remaja Rosdakarya.

Morgenthau, H J. (2005). Politics Among Nations: The Struggle For Power And Peace. Boston: McGraw-Hill Higher Education

Nasution, P. (2005). Adat Budaya MANDAILING Dalam Tantangan Zaman. Medan: FORKALA (Forum Komunikasi Antar Lembaga Adat Prov. Sumatera Utara).

Nasution, I.M, (2016). Biografi Willem Iskander Tokoh Pencerah dan Pembaharu Bangsa. 1840-1876. Medan: Buletin Sinondang Mandailing.

Nugroho, R. (2004). Public Policy. Jakarta: Elexmedia Komputindo

Narwoko, J.D. \& Suyanto, B. (2010). Sosiologi Teks Pengantar \& Terapan Edisi keempat. Jakarta: Kencana Prenada Media Group.

Organsky, A.F.K. (1985). Tahap-Tahap Perkembangan Politik. Akademika Pressindo; T.P

Parinduri, M.B. (2017). Religi-tradisi-atraksi. Medan: Buletin Sinondang Mandailing 
Purnomo, D. \& Chuzaimah. (2004). Studi Tentang Niatan Menetap Migran Sirkuler (Kasus Migran Sirkuler Asal Wonogiri Ke Jakarta). Jurnal Ekonomi Pembangunan (JEP) Vol.5 No.2 Desember 2004.

Rochajat, H. dan Ardianto, E. (2011). Komunikasi Pembangunan dan Perubahan Sosial. Jakarta: PT. Raja Grafindo Persada.

Rustiadi, E., Saefulhakim, S, \& Panuju, D.R. (2011). Perencanaan dan Pengembangan Wilayah. Jakarta: Yayasan Pustaka Obor Indonesia

Subandi. (2011). Ekonomi Pembangunan (cetakan kesatu). Bandung: Alfabeta

Sartori, G. (1973). What is "Politics", Political Theory, vol.1, no.1

Soekanto, S. (2006). Sosiologi Suatu Pengantar. Jakarta: PT RajaGrafindo Persada

Sutiyono, (2010). Benturan Budaya Islam: Puritan dan Sinkretis. Jakarta: Kompas
Tjokrominoto, M. (2007). Pembangunan: Dilema Dan Tantangan. Yogyakarta: Pustaka Pelajar. Usman, P. (1994). Urbanisasi dan Adaptasi (Peranan Misi Budaya Minangkabau dan Mandailing). Jakarta: LP3ES.

Warjio. (2013). Politik Pembangunan Islam Pemikiran dan Implementasi, Medan: Perdana Publishing.

Warjio. (2016). Politik Pembangunan: Paradoks, Teori, Aktor dan Ideologi, Jakarta: Kencana.

wahyudi, 2015 dalam http://digilib.uinsby.ac.id/3200/5/Bab\%20 2.pdf

http://file.upi.edu/Direktori/FIP/JUR._PSIKOLOGI/ 195009011981032RAHAYU_GININTASASI/KELOMPOK_SOSIAL. pdf 